\title{
Industry Demands and Future of Engineering Education in Kenya
}

\author{
http://dx.doi.org/10.3991/ijep.v5i2.4453 \\ Daniel .M. Rutto \\ University of Rwanda, Kigali, Rwanda
}

\begin{abstract}
Engineering Education in Kenya remains the major determinant of country's economic agenda. However, at the moment the education system offers the industry and society unsatisfactory knowledge and services due to mismatch between the supplied educational talents and the ever changing world of engineering. It is imperative that the Kenyan engineering education be designed to tackle challenges emerging in our societies and industries by providing real tangible practical skills. The government on its part should take its share by supporting and giving direction to institution offering such courses. In order to produce graduates with employable skills, institutions of engineering must aim at quality while ensuring massification of students into programs never happens. This paper is thus designed to show challenges facing quality of engineering education offered in Kenya in relation to the society and industrial needs. The paper also highlights the future demands needed on Kenyan engineering education. The write-up is expected to inspire education designers and curriculum developers in preparing programs that provide for the society and industry.
\end{abstract}

Index terms-Engineering education, industry, skillsmismatch, society,

\section{INTRODUCTION}

Kenya like most other developing countries spends approximately $20 \%$ of its gross national product in educating its young people from primary schools to tertiary institutions $[1,2]$. This continuous investment of such a large percentage of the product of wealth generating industry and commerce ought to be done with a clear sense of countrywide preference, an evident relevance to the continued economic success of the country, and a cautious management upon its effectiveness.

Different countries use different approaches in teaching depending upon the designed teaching model chosen. Such models initiated for better learning process are usually dependent on economic capabilities of each nation. This then suggest that different problems are faced in many countries, and the degrees of interdependence between countries today leads inevitably to a convergence in the answers which are agreed-upon [3].

Few countries are either sufficiently wealthy, or have the will to provide the means to spend all that would be wished by the educational practitioners to meet all these pressures. In Kenya the overall university student enrolment increased by 34.9 per cent from 240,551 in $2012 / 13$ to 324,560 in $2013 / 14$. The increase is attributable to higher enrolment levels in the public universities following the introduction of new courses in addition to upgrading of university colleges. Male student enrolment in- creased by 42.6 per cent from 135,436 in $2012 / 13$ to 193,185 in $2013 / 14$ while female student enrolment rose by 25.0 per cent to 131,375 in $2013 / 14$. During the same period, enrolment at public universities increased by 41.3 per cent from 195,528 in $2012 / 13$ to 276,349 in $2013 / 14$. Enrolment in private universities increased by 7.1 per cent from 45,023 in 2012/13 to 48,211 in 2013/14 [4]. Out of this figure just a small fraction of students do enroll for engineering. Some of the enrolled students are even differing or changing their engineering courses all together.

Massification has changed the traditional client base of the university with more students demanding education and with more mature students seeking life-long learning through continuing education programs. International competition has added further pressure for change, forcing universities to become more concerned about knowledge production, innovation and relevance of their activities to the external environment. The explosion in technology and information sciences in the sciences have created a new skills base within the traditional university and forced changes in the curriculum in what is called "mode 2 form of knowledge production". As a consequence, the arts and science related courses have declined, and the "enterprise professions" have become dominant as reflected in areas such as business, management and accountancy [5].

Growing human capital is critical to the economy of developing countries. It is hoped that with close cooperation with business and industry, Kenyan universities will help close Africa's existing skills gap by ensuring that the globally competitive human capital they produce is equipped with the capabilities demanded in the modern world economy [6]. The country must find better, cheaper, safer, less harmful, more energy-efficient ways of doing things. It is high time the country uses an engineering approach to bring in a better engineering education process for the generations to come.

\section{TRENDS IN ENGINEERING EDUCATION}

\section{A. Engineering Education in the United States}

Engineering education in developed countries has changed considerably during recent years. Not only has the number of graduates in traditional engineering disciplines such as mechanical, civil, electrical, chemical, and aeronautical engineering declined, but in most of the premier universities, engineering curricula now concentrate on and encourages largely the study of engineering science [7].

In United States there is a new demand of engineers who can play more roles in coordinating, outsourcing and supplier chain management [8]. However, as the country is preparing to tackle this issues, the National Science 
Board is issuing several reports expressing concern about long-term trends that affect U.S. workforce capabilities in engineering, including the dependence on international students and workers; the declining interest on the part of U.S. citizens in engineering studies and careers; weakness in the K-12 science, technology, engineering, and mathematics (STEM) education system; and demographic trends that are unfavorable to increasing citizen participation rates in these fields [9]. There is also declining offerings in engineering subjects dealing with infrastructure, the environment, and greater concentration has been put on high technology subjects, largely supporting increasingly complex scientific development [7]. Despite a reduction in the number in United State it is however noted that $81 \%$ of their graduates are standards-compliant with the wishes of both industry and education system [8]. This has in turn made the United States a global leader in supply of highquality engineering talent [10].

\section{B. Engineering education in China}

Chinese engineering education on the other hand has made significant achievements in the recent years. The scale of education has been rapidly expanding and a higher education system with wide range of disciplines and multi levels has been gradually formed. It is noted that engineering is the largest discipline in Chinese higher education. In 2011 there were 2222 institutions that had undergraduate engineering programs, this accounted for $92.2 \%$ of the total 2409 higher education institutions. The enrollment of undergraduate and graduate engineering students were 8.689 million and 0.588 million respectively, both accounting for over one third of the total enrollment numbers. The increase is further supported by graduate enrollment in 2010, where professional students accounted for $41 \%$, of which $47 \%$ were undertaking master of Engineering [11]. Hence Chinese engineering education is the biggest one in the world and is proportionate to the country's needs towards its fast growing economy.

In spite of the momentous realization of engineering education in China, there are still many issues and challenges to deal with. The most obvious revolves around the mismatch between supply and demand of talents that is desperately needed by the industry. A prominent problem is that while university graduates from many majors have difficulty in finding jobs; the society is in desperate need of practical talents, especially skilled talents. This is because Chinese engineering education focuses on knowledge accumulation, knowledge dissemination and the construction of knowledge systems, unlike the one for United States which emphasizes more attention on training students to master knowledge and practical ability [8]. The biggest reason affecting the quality of engineering education in China is that the development goals and models used by colleges and universities tend to be homogeneous i.e. institutions tends to compare themselves to top universities without considering their own realities and the needs of the industry.

\section{Engineering Education in sub-Saharan Africa (SSA)}

Technological transformations have rendered many formerly scarce resources abundant, while the key constraints on economic and business development have become the skills, knowledge, and talent embodied in individual workers. Economic success and failure will increasingly be determined by the strategic acquisition and management, by businesses and individuals, of economi- cally-relevant skills [12, 13]. Despite a clear knowledge gap required by industries, SSA suffers unending need of home-grown capabilities in engineering. Statistically there are a few engineers graduating compared to demands of the countries in the region. On the other hand, there is high rate of unemployment among engineering graduates, indicating that the problem is more complex than a simple lack of numbers. Unemployment among engineering graduates may, in part, be due to reluctance on their part to take poorly paid positions in rural areas, or due to foreigners engineers employed firms who prefer foreign labour [14]. However, the major reason identified is that engineering students are graduating with unemployable skills [15]. Hence institutions offering engineering courses are outputting a substantial number of graduates with few of them equipped with sufficient skills and experience.

A number of the root causes of low capacity in SSA relate to government policies or approaches to engineering. A low level of public investment in engineering projects over several decades has meant an inconsistent demand for qualified engineers [16]. To some degree, this underinvestment may be due to the politicization of the education engineering agenda or a basic failure of policy makers to understand engineering issues. Of the professional engineers in SSA, $42 \%$ believe policymakers have a poor understanding of engineering issues, while only $14 \%$ are believed to understand the issues at hand $[14,16]$. This is also supported by [17] where it is believed that mobilizing resources and people, and providing overall direction in education should be the main responsibility of government. Aside from the problem of underinvestment, governments in SSA also often fail to legislate sufficiently to safeguard engineering standards. The reputation of the engineering profession may partly depend on the existence and enforcement of legal requirements for engineers to be professionally registered before being allowed to practice at certain levels [18].

Human capital flight is also another problem affecting education system in Africa. There has been an outflow of skilled personnel to developed countries. This is a result of a number of issues among them poor working conditions, low salaries, big classes, conflict, and declining funding opportunities [19]. This compromises educational quality. In South Africa in the early 2000s the number of engineers emigrating annually actually matched the numbers graduating. While the number leaving was partially offset by a steady flow of engineers into South Africa from poorer countries on the continent, this in turn undoubtedly had a detrimental effect on the countries those engineers left behind. As well as moving to other countries, talented engineering graduates are also lost to non-engineering sectors such as banking, finance, IT and management consultancy. It is believed that jobs in finance or government are seen as more prestigious and so attracted talent away, even from more lucrative engineering sectors [14].

\section{ENGINEERING EDUCATION IN KENYA}

Kenya lacks enough engineers, technicians and artisans required to propel the country to an active middle economy. With such a skills gap, Kenyan economic growth prospects faces uncertain future despites its current huge infrastructure budget and massive ongoing projects. The Vision 2030 further notes that their exist shortfall in the supply of science, engineering and technology (SET) graduates in the country [20]. The skills gap is further 
compounded by weak linkages between the private sector and the education and training offered to students, resulting in a disparity between the supply and demand for skills [21]. Therefore, the maximum impact in terms of employment generation can be achieved by developing the skills and experiences that are in line with the private sector dynamics.

The ratio of engineers to technologist to technicians to craft/artisans for most developed countries for the four categories of professional is 1:2:4:16, however for developing countries however, it is considered that the more realistic ratios is $1: 3: 12: 60$. It is however estimated that for technological take-off, a country should be having at least 500 engineers and engineering technologists to 1 million people of the population. Examples in this respect are: China - 1 engineer for 130 persons, India - 157, Brazil - 227, UK - 311, USA - 389, Malaysia - 543, South Africa - 3166, Tanzania - 5930, Namibia - 6346, Kenya 6300, Zimbabwe - 6373, and Swaziland - 12,238. By 2030 , Kenyan population is projected at 60 million. At the point of industrial takeoff, Kenya as a country should be having some 30,000 engineers and engineering technologists. This means then that the economy will require at least 7,500 engineers, 22,500 engineering technologists, 90,000 engineering technicians, and 450,000 craft/artisans [22].

As a result of low employment rate and ever changing industry demands, there has been a continuous need to broaden the syllabus by allowing students to undertake more courses coupled with business courses. This is so because employers are concerned to see an engineer with broader engineering content, and the ability to transform engineering problems into viable opportunities which are geared towards profit making [23]. However such curriculum will mean more additional years of schooling in addition to the usual five year courses that most engineering institution find to be too long and in appropriate. In addition the continuing expansion of an already crowded course is certainly a factor contributing to the perceived falling number of students attracted to engineering courses in future. The little number of available reading materials may be seen to compromise quality [24, 25]. All this is taking place alongside an environment in which ministry of higher education in Kenya is under increasing financial pressures, and there are great dangers that standards will fall due to inadequate government sponsorship.

\section{ENGINEERING EDUCATION AND WEALTH CREATION}

The Kenyan wealth creation and the quality of engineers produced by the universities have to rally together with one common goal that is setting the base and advancing the country towards industrialization by the year 2030 . It should be clear that the industry and commerce, is anxious to achieving excellence in its engineering functions with no tolerance or losses. The Kenyan government must recognize that engineering industry creates the national wealth, pervade society, and provide the infrastructure to the society. This will in turn bring the society and engineering education at equilibrium.

Kenyan Higher education has a task to persuade the society that it has the ability and will to improve on the quality of engineering education, but cannot alone correct a system that may be out of balance. Thus if high quality students are not attracted in sufficient quantity into cours- es leading to honors degrees in engineering, it is due, to a great extend, to society's and industry's perception of the value of the chartered engineer. It will not be corrected by increasing or even maintaining the supply of lower quality engineering graduates. That will indeed confirm those perceptions, and compound the problem.

The better response will be to maintain or raise standards, and accept fewer into such courses. Although the market operates slowly, the most certain way of changing the perceptions of industry is by reducing the quantity, and increasing the quality of the Chartered Engineer. The problem faced by the universities in following such a course is to keep industries satisfied while the society, as represented by government, is anxious only at seeing increasing numbers of engineers' studies in higher education.

There is also a tension between the student and the employer.

The students' expectations are:

i. To secure the qualification that will establish him/her in a career providing security, interest, money, and opportunities for high position.

ii. To pursue an interest in engineering matters that will provide him/her with the opportunity to extend that interest into a career.

The employers' expectations are to attract:

i. A few high calibers, flexible entrants who will be expected to progress into the management of engineering.

ii. Proportional numbers of skilled entrants who are able to undertake a broad range of technical tasks in relation the available tasks within a specified time and budget.

It is not evident that all those students who expect high position will satisfy the employers' criteria, nor will all who wish to be engaged in the most challenging of engineering tasks find many of the jobs with which they are confronted to be satisfying. Thus one of the dilemmas faced by higher education is to help satisfy the different criteria held by the various customers. This is because the engineering industry are after reducing cost of production to minimum while maximizing profits, hence employers are seen to give jobs to those who have the right knowledge in certain specific areas of engineering courses.

\section{The Present And Future Expectations Of STUDENT ENGINEERS}

Applications to study in the university have been rising since the introduction of privately sponsored student program in Kenya (PSSP) [26]. These new university entrants have found the field of study very much attractive. This has happened despite low available chances of one getting permanent employment in a given firm. Engineering education in Kenya just like many other countries does not attract the highest caliber of university entrants, as most of them end up studying human medicine, pharmacy, and architecture. Most engineers graduating from Kenyan colleges find the new working environment completely independent from class work. This then creates apparent disappointment due to their first experience at work. This implies a mismatch between the anticipation engendered 
during undergraduate years, and the realism of the working place.

\section{The CHALLENGE FACING ENGINEERING EDUCATION IN KENYA}

Globalization has changed the skills and competencies required from engineers being hired by industry and service providers. As a result the responsibility of schools of engineering in educating and training engineers needs to be altered significantly. It is now an obligatory for engineering graduates to have multi-skills, flexibility, managerial competencies and work ethics. Engineering curricula has to ensure that graduating engineers can meet the current prospects of the industry. The industry desires engineers that are locally relevant and globally aggressive. They should be competent in solving local problems and also invent new products and services within the country.

Schools of Engineering have to revamp and improve their curricula to meet the anticipation of industry. The formal education system has to be supplemented with a modular system of education whereby engineers are able to acquire skills and competencies on a continuous basis through the use of open ended problem solving technique. Engineers must be capable of learning new skill in fast and cautious way to meet the ever-changing requirements of their employers. Educational systems should present courses based on e-learning using web-based tools. These courses should be offered to the working and learning engineers. This should be done taking into contemplation the engineer's specific requirements for fresh knowledge and skills.

Rapid paced industrial changes are driving certain engineering and production firms into oblivion. The result of this is that engineers must be capable of participating in long-term education programs in partnership with industry. The capability profile of engineers is changing radically. Schools of engineering can no longer design their educational programs on their own. It is vital to institute a close collaboration amid schools of engineering and industry in order that they may both contribute in the formation of engineers who can withstand the taste of time.

\section{ENGINEERING EDUCATIONAL PROGRAMS CHANGES}

In the last three decades, engineering and technical education in developing countries has witnessed large growth. A majority of these institutes of higher education have relatively good infrastructure and qualified teaching staff. However, the general efficiency and effectiveness in utilizing these resources is lacking. Presently, the focus in engineering education in developing countries is on teaching the basics of technology [27]. Only a few institutes can offer their student knowledge pertinent to the needs of industry, the industry on the other hand cannot dictate the type and contents of curriculum to be used by learning institutions [28]. Some faculties of engineering have included within their curriculum short periods of time to be spent in the corporate environment. Most other faculties lack a comprehensible vision regarding strategies needed to inform their students about the future needs of industry. Thus, there is an urgent need for an important change in perspective and in the model used in establishing new curricula.

\section{EFFECT OF GLOBALIZATION ON ENGINEERING EDUCATION IN DEVELOPING COUNTRIES}

Foreign universities have started opening educational centers in developing countries and are tying-up with various established universities [27]. Such educational centers are providing engineering students with a wide variety of choices and state of the art curricula, which can provide global career opportunities. However, in Kenya this has been limited mainly to medicine, IT and business courses. Some of the more important outcomes of the analysis are that future engineering education in Kenya must take the following into consideration:

i. Redesign curricula and involve industry in the development of these new curricula. Degree programs should allow students flexibility; at the same time offer employable skills as industries shift. New models of knowledge, production, access and distribution are emerging which include: open source, knowledge communities, and emphasis on networks. Qualitative Shifts in Engineering Education must react to these playing fields of the knowledge based economy.

ii. Use of advanced lecture delivery tools such as projectors, e-learning via intranet and internet.

iii. Offer courses at global level through web-based learning tools.

iv. Offer collaborative learning environment by tying up with leading foreign universities and corporations like student exchange programs.

Engineering educational programs must prepare engineers capable of meeting the needs of industry. Faculties of engineering must be fully aware of some important facts such as:

i. Understand that employers of engineers are multinational companies with wide geographical spread and conduct business across international boundaries.

ii. Engineers must deal with varied cultures, customs and languages and must be capable of working in global rather than local environments.

iii. Engineering work must adhere to a variety of statutory and regulatory requirements.

iv. Engineering designs need to address both local and international requirements, and in particular, environmental regulations.

v. Developed products must address a variety of customers and consumer preferences.

Changes of engineering curricula should address new methods in teaching and learning and in their content.

Some of these must include the following:

i. Part of graduation requirements could be fulfilled through a period of study abroad.

ii. Implement faculty and student exchange programs to clarify the global views of the engineering practice. This will make Degrees more translatable as graduates may head abroad for job opportunities.

iii. Inclusion of extended periods and/or close cooperation with industry while enrolled in the faculty of engineering.

iv. Conducting joint projects/research among various departments (multi-disciplinary) and among differ- 
ent universities in different geographical locations and countries.

v. Engineering curricula must include languages and cultural studies.

vi. Engineering programs accreditation must be made global and subject to international quality standards that address industrial expectations (e.g. ISO certification Standard).

vii. Ensure that engineering students are educated in how to develop their critical thinking abilities, innovation and problem solving techniques by offering projects at various stages of their years within the faculty of engineering and not just at the end of the program. Engineers have to remain skillful working in today's cooperative work environments by demonstrating effective leadership, possessing good communication skills, and complex thinking abilities.

New Engineering curricula must address the following:

i. Clarify the impacts of technological change on societies.

ii. Stress the need to make information technology part of engineering education.

iii. Offer basic foundations of science and mathematics and offer opportunities for the inclusion of biology, energy and water technologies.

iv. Offer opportunities for specialized knowledge without ignoring multi-disciplinary content of the curriculum.

$\mathrm{v}$. Teach engineering students the real value of teamwork and stress the need for clear communication including verbal, written and visual. New employees in any industry must be flexible and highly skilled in a variety of competencies. This Skills and competencies that are increasingly valued need one to be Versatile, and multi-faceted. Engineers today should therefore not only have high-level technical skills but also must possess the "soft" skills, and "People" skills which are working in groups, teams, leadership.

vi. Students must have technical/specific skills in relevant fields, but also solid background knowledge to adjust work to the market. Students must be taught engineering as well relevant basic elements of business, finance, management and quality.

\section{CONCLUSION}

If the next Kenyan generation of engineers are to be "more than technical functionaries in the $21^{\text {st }}$ century, there is a need to provide young engineers with knowledge of the social environment within which they will work, together with skills in decisive analysis and ethical judgment and an ability to assess the long-term consequences of their work" [29]. To solve the big problems facing Kenya and other developing countries, the next generation of engineers will need a set of knowledge, skills, and attitudes that are sufficiently strong technically and broad enough regarding non-technical understanding of social, economic, and political systems. Creativity, or the ability to see the world anew, making the strange familiar and the familiar strange, can help infuse a sense of purpose in education and help students learn to appreciate and work within the frame work of engineering.

\section{REFERENCES}

[1] Institute of economic affairs, "Budget guide" Retrieved 0108 , 2015, from www.ieakenya.or.ke, 2014

[2] UNESCO, "Teaching and learning: Achieving quality for all" Retrieved $01 \quad 08, \quad 2015, \quad$ from http://unesdoc.unesco.org/images/0022/002256/225660e.pdf, 2014

[3] Maviiri J. C. "Trading or Sharing - Emerging opportunities and challenges for Cross Border Higher Education in East Africa" Retrieved $01 \quad 08, \quad 2015 \quad$ from aiu.net/conferences/Utrecht/presentations/B4_Maviiri_paper.pdf, 2006

[4] KNBS, "Economic survey 2014" Retrieved 01 09, 2015, from http://www.knbs.or.ke/, 2014

[5] Gibbons, Limoges, Nowotny, Schwartzman, Scott, \& Trow, "The New Production of Knowledge:The Dynamics of Science and Research in Contemporary Societies" London: SAGE Publications Ltd, 1994

[6] Riechi, "Demand for academic programmes offered in Kenya's public universities and their relevance to the labour market" Retrieved $11 \quad 02, \quad 2014, \quad$ from http://www.csae.ox.ac.uk/conferences/2008-edia/papers/265riechi.pdf, 2008

[7] Frankel, (2008). Changes in Engineering Education: Massachusetts institute of technology. Retrieved 1101,2015 from http://web.mit.edu/fnl/volume/205/fnl205.pdf

[8] Zhang, \& Bai, "Comparative Study on Engineering Education in China and USA" Retrieved January 25, 2015, from http://www.wpi.edu/Pubs/E-project/Available/E-project-082509 224412/unrestricted/Final_Report.pdf, 2009

[9] [9] NSB, "Moving forward to improve engineering education" Retrieved Jnuary 29, 2015, from http://www.nsf.gov/pubs/2007/nsb07122/nsb07122.pdf, 2007

[10] Gereffi, Wadhwa, Rissing, \& Ong, "Getting the Numbers Right:International Engineering Education in theUnited States, China, and India" Journal of engineering education , 13-25, 2008 http://dx.doi.org/10.1002/j.2168-9830.2008.tb00950.x

[11] Gaofeng, "The Status and Prospects of Engineering Education in China" Retrieved January 26, 2015, from http://www.mernokakademia.hu/2013conf/abstrakt/6The\%20Statu s\%20and $\% 20$ Prospects $\% 20$ of $\% 20$ Engineering\%20Education $\% 20 \mathrm{i}$ $\mathrm{n} \% 20$ China.pdf, 2013

[12] Baale, "The greatest danger to African leaders-youth unemployment" Retrieved February 03, 2015, from http://lerebaale.blogspot.com, 2013

[13] Manpowergroup, "Youth unemployment challeges and opportunities: What business can do now" Retrieved February 03, 2015, from http://www3.weforum.org/docs/Manpower_YouthEmploymentCh allengeSolutions_2012.pdf, 2012

[14] Matthews, Ryan-collins, Wells, Sillem, \& Wright, "Engineers for africa:Identifying engineering capacity needs in Sub-Saharan Africa" Royal Academy of engineering, 2012

[15] EARC, “Country strategic paper 2014-2018” African development bank group, 2014

[16] ReConnect Africa magazine, "Engineering Africa" Retrieved February 03, 2015, from http:/www.reconnectafrica.com/MarchApril-2014/africa/engineering-africa.html,

[17] Ramos, "Science and technology for development in Sub-Saharan Africa: Key topics, challenges and opportunities" London: SciDev.Net, 2014

[18] National council for law, "The engineers ACT, 2012" Retrieved from www.kenyalaw.org, 2012

[19] GUNi;IAU;AAU, “The promotion of sustainable development by higher education institutions in Sub-Saharan Africa” Retrieved January 27, 2015, from http://www.aau.org/sites/default/files/esb/promotion_of_sd_by_H EIs_sub_saharan_africa.pdf, 2011

[20] Karimi, Mkandawire, Salieu, Muvawala, Owuor, Takei, et al, "Support to enhancement of quality and relevance in higher education, science and technology project: Project appraisal report 2012" Retrieved February 03, 2015, from 
PAPER

INDUSTRY DEMANDS AND FUTURE OF ENGINEERING EDUCATION IN KENYA

http://www.afdb.org/fileadmin/uploads/afdb/Documents/Projectand-Operations/Kenya, 2012

[21] Awuor, "Graduate unemployment and unemployability in Kenya: Transforming university education to cope with market demands and the lessons for Africa" International journal of social sciences tomorrow , 1-12, 2013

[22] Some, "Recent developments in higher education sector" Retrieved February 03, 2015, from http://www.kapkenya.org/pdfs/KAP.pdf, 2013

[23] King, "Restructuring Engineering Education: Why, How and When?" Retrieved January 29, 2015, from http://www.cshe.berkeley.edu/sites/default/files/shared/publication s/docs/ROPS.12.11.King.EngineeringEd.9.29.11.pdf, 2011

[24] Kinyanjui, "The transformation of higher education in kenya: challenges and opportunities" Commission of Higher Education, 2009

[25] Sharma, "Expansion of Engineering Education in India: Issues, Challenges and Achievable Suggestions" Journal of Academia and Industrial Research (JAIR) , 118-122, 2014
[26] Commission for University education, "Strategic plan 2014-2018" Retrieved 01 08, 2015, from http://www.cue.or.ke/aboutus/strategic-plan, 2014

[27] Sanjay, et al, "Impact of globalization on engineering education in developing countries" 2008

[28] NSF, "Transforming Undergraduate Education in Engineering" American Society for Engineering Education, 2013

[29] Beder, "Beyond Technicalities: Expanding Engineering Thinking," Journal of Professional Issues in Engineering Education and Practice, 125(1), 12-18, http://dx.doi.org/10.1061/(ASCE)1052-3928(1999)125:1(12)

\section{AUTHOR}

Daniel M. Rutto is a lecturer working with University of Rwanda, school of Engineering (e-mail: dmrutto.dr@ gmail.com).

Submitted 29 March 2015. Published as resubmitted by the authors 07 May 2015. 